\title{
Activation of PPAR $\gamma$ by Rosiglitazone Does Not Negatively Impact Male Sex Steroid Hormones in Diabetic Rats
}

\author{
Mahmoud Mansour, Elaine Coleman, John Dennis, Benson Akingbemi, Dean Schwartz, \\ Tim Braden, Robert Judd, Eric Plaisance, Laura Ken Stewart, and Edward Morrison
}

Department of Anatomy, Physiology and Pharmacology, Auburn University, AL 36849, USA

Correspondence should be addressed to Mahmoud Mansour, mansoma@auburn.edu

Received 22 December 2008; Revised 17 March 2009; Accepted 29 April 2009

Recommended by Carolyn Komar

Peroxisome proliferator-activated receptor gamma $(\operatorname{PPAR} \gamma)$ activation decreased serum testosterone (T) in women with hyperthecosis and/or polycystic ovary syndrome and reduced the conversion of androgens to estradiol (E2) in female rats. This implies modulation of female sex steroid hormones by PPAR $\gamma$. It is not clear if PPAR $\gamma$ modulates sex steroid hormones in diabetic males. Because PPAR $\gamma$ activation by thiazolidinedione increased insulin sensitivity in type 2 diabetes, understanding the long term impact of PPAR $\gamma$ activation on steroid sex hormones in males is critical. Our objective was to determine the effect of PPAR $\gamma$ activation on serum and intratesticular T, luteinizing hormone (LH), follicle stimulating hormone (FSH) and E2 concentrations in male Zucker diabetic fatty (ZDF) rats treated with the PPAR $\gamma$ agonist rosiglitazone (a thiazolidinedione). Treatment for eight weeks increased PPAR $\gamma$ mRNA and protein in the testis and elevated serum adiponectin, an adipokine marker for PPAR $\gamma$ activation. PPAR $\gamma$ activation did not alter serum or intratesticular T concentrations. In contrast, serum $\mathrm{T}$ level but not intratesticular T was reduced by diabetes. Neither diabetes nor PPAR $\gamma$ activation altered serum E2 or gonadotropins FSH and LH concentrations. The results suggest that activation of PPAR $y$ by rosiglitazone has no negative impact on sex hormones in male ZDF rats.

Copyright (C) 2009 Mahmoud Mansour et al. This is an open access article distributed under the Creative Commons Attribution License, which permits unrestricted use, distribution, and reproduction in any medium, provided the original work is properly cited.

\section{Introduction}

Peroxisome proliferator-activated receptors (PPARs) are a group of nuclear transcription factors which belong to the steroid receptor superfamily but are not activated by steroid hormones. Three PPAR isotypes have been identified and include PPAR $\alpha$ (NR1C1), PPAR $\beta$ (NR1C2, $\delta$, NUC-1, fatty acid-activated receptor (FAAR)), and PPAR $\gamma$ (NR1C3). A large number of both endogenous (natural) and exogenous (synthetic) ligands activate either a single PPAR isoform or all isoforms, albeit with different binding affinities and specificities [1]. Among the important PPAR $y$ synthetic activators are the thiazolidinediones (TZDs) drugs often used in the treatment of type 2 diabetes. These include Avandia (rosiglitazone), Actos (pioglitazone), a combination drug, Avandamet (rosiglitazone and metformin), and Rezulin (troglitazone). Troglitazone was withdrawn from the market because of idiosyncratic liver toxicity. Activation of PPAR $y$ by TZDs increases insulin sensitivity and thus improves body glycemic control $[2,3]$.

PPARs are involved in a broad range of functions that include lipid homeostasis [2], tissue remodeling, angiogenesis, prostaglandin production [3], and steroidogenesis [4]. Additionally, PPARs also regulate inflammatory pathway by transrepression of transcription activity of proinflammatory transcription factors such as nuclear factor $\kappa \mathrm{B}(\mathrm{NF}-\kappa \mathrm{B})$ [5]. Likewise, several data implicate PPARs in regulation of profibrotic [6-8] and oxidative stress responses in several cell types [9-11].

Support for the hypothesis that activation of PPARs, specifically $\operatorname{PPAR} \gamma$, has an impact on sex steroid hormones action and/or production comes from several TZDs studies including two studies in male subjects [4, 12-22]. A study in healthy nondiabetic men showed that rosiglitazone treatment $(8 \mathrm{mg} / \mathrm{d}$ for seven days) reduced the production rate of testosterone $(\mathrm{T})$ and dihydrotestosterone (DHT) 
[14]. Similarly, rosiglitazone treatment of obese nondiabetic Zucker rats $(0.01 \% \mathrm{wt} / \mathrm{wt}$ food admixture equivalent to $4 \mathrm{mg} / \mathrm{kg} / \mathrm{d}$ for 36 days) reduced DHT but did not alter serum $\mathrm{T}[22]$.

Multiple studies using ovarian and other cell culture models support a steroidogenic role for PPAR $\gamma$. First, activation of PPAR $\gamma$ with troglitazone, a TZD insulin sensitizer and putative PPAR $y$ agonist, inhibited aromatase cytochrome P450 activity, the enzyme critical in the conversion of androgens to estradiol (E2), in human adipose tissue [15] and in ovarian granulosa cells [20]. Similarly, activation of PPAR $y$ by troglitazone in vitro cultures of human and porcine granulosa cells inhibited progesterone production [4]. Troglitazone was also reported to competitively inhibit $3 \beta$-hydroxysteriod dehydrogenase ( $3 \beta$-HSD), the enzyme that catalyzes the conversion of pregnenolone to progesterone in the ovary [16]. Likewise, troglitazone was shown to inhibit androgen biosynthesis stimulated by combined LH and insulin in primary porcine thecal cell culture in a dose-dependent fashion [17].

In human adrenal NCI-H295R cells, an established in vitro model of steroidogenesis of the human adrenal cortex, both rosiglitazone and pioglitazone inhibited the activities of P450c17 and 3 $\beta$-HSD type II both of which are key microsomal enzymes in the biosynthesis of all steroid hormones [18]. In diabetic women with polycystic ovarian syndromes (PCOs), a condition characterized by anovulatory androgen secretion, relatively high E2, and excessive LH production [23-25], treatment with the PPAR $\gamma$ agonists rosiglitazone or pioglitazone improved insulin resistance and decreased hyperandrogenism in multiple studies (reviewed in [26-28]).

Toxicological studies showed that phthalate esters, used as plasticizers and stabilizers in several consumer products, activate PPAR $y$ [29], decrease key testicular steroidogenic enzymes [30] and reduce serum T production [31-34].

Although it is axiomatic that steroidogenic inhibition is a general characteristic of TZD compounds, involvement of PPAR $y$ and rosiglitazone in steroidogenic modulation under diabetic conditions remains unclear for several reasons. First, a study showed that the in vitro $\mathrm{IC}_{50}$ for rosiglitazone steroidogenic inhibition is far beyond its recommended therapeutic dose [13]. Second, a number of studies showed that TZDs, including rosiglitazone, directly inhibit 3 $\beta$-HSDII and P450c17 steroidogenic enzymes independent of PPAR $\gamma[13,18]$. Third, in the aforementioned male studies PPAR $\gamma$ activation was not determined in parallel with sex hormone measurements. More importantly none of the research subjects used was diabetic where the steroidogenic effect of diabetes is an important component for evaluation of TZDsPPAR $y$ activators. Finally, the treatment period used in the aforementioned male studies was short and varies between 7 and 36 days. Because of the above limitations, the objective of this study was to determine the link between relatively short term (8 weeks) activation of PPAR $y$ and the profile of T and E2 in male Zucker diabetic fatty rats (ZDFs) treated with a therapeutic dose of rosiglitazone.

\section{Materials and Methods}

2.1. Animals and Treatments. Male ZDF (fa/fa) rats and their age-matched lean controls (ZDF lean, fa/ + or $+/+$ ) were obtained from Charles River Laboratories (Indianapolis, Ind, USA) at 6 weeks of age. The (fa/fa) ZDF rats lack a functional leptin receptor and become hyperphagic and diabetic when fed a high fat diet. Rats were maintained under standard housing conditions (constant temperature of $22^{\circ} \mathrm{C}$, ad libitum food and water, and 12:12 hours light/dark cycles) at an AAALAC-accredited lab animal facility at the College of Veterinary Medicine, Auburn University. Rats were housed in pairs and assigned to three groups with 8 rats per group. Lean nondiabetic group (group 1); ZDF rats randomly assigned to ZDF untreated group (group 2) and ZDF group treated with rosiglitazone (group 3). Lean rats were fed regular rat chow whereas ZDF rats in group 2 and 3 were fed Purina 5008 modified rat chow (Purina Mills, Richmond, Ind, USA). Rosiglitazone maleate (generously provided by GlaxoSmithKline, USA) was dissolved in $0.5 \%$ carboxymethylcelluose and administered daily via oral gavage at $3 \mathrm{mg} / \mathrm{kg} / \mathrm{d} /$ rat starting at week 7 of age for 8 weeks. Rats in groups 1 and 2 received 0.5\% carboxymethylcelluose vehicle. All rats were weighed and blood glucose was monitored from the tail vein weekly using an ACCU-CHEK glucose meter (Roche Diagnostics Co. Indianapolis, Ind, USA). Diabetes was confirmed by two consecutive measurements of blood glucose of $>200 \mathrm{mg} / \mathrm{dl}$. All animal procedures were approved by the Institutional Animal Care and Use Committee at Auburn University.

2.2. Necropsy and Tissue Collection. Rats were sacrificed by deep anesthesia with pentobarbital $(50 \mathrm{mg} / \mathrm{kg}$ intraperitoneal, IP) followed with decapitation. Testes were excised, and sampled for histopathology, RNA extraction, and intratesticular T assay. Visceral epididymal fat and prostate were collected for use as positive sources for PPAR $y$ expression in real-time PCR analysis. Tissues intended for RNA and hormone analysis were immediately frozen in liquid nitrogen and transferred to $-80^{\circ} \mathrm{C}$ until processing. Trunk blood was collected for serum isolation and stored at $-30^{\circ} \mathrm{C}$ prior to hormone analysis.

2.3. Total RNA Isolation. Total RNA was isolated using TRIzol reagent (Invitrogen-Life Technologies Inc., Carlsbad, Calif, USA), according to the manufacturer's instructions and as described previously in our laboratory [35]. Briefly, RNA concentrations were determined at $260 \mathrm{~nm}$ wavelength and the ratio of 260/280 was obtained using UV spectrophotometry (DU640, Beckman Coulter Fullerton, Calif, USA). RNA samples were treated with DNase (Ambion Inc.) to remove possible genomic DNA contamination and samples with $260 / 280$ ratio of $\geq 1.8$ were used.

2.4. Real-Time PCR and Agarose Gel Electrophoresis. Realtime PCR was used to determine expression of testicular PPAR $y$ mRNA and to quantify changes in mRNA level. Quantitative real-time PCR analysis was performed 
in $25 \mu \mathrm{L}$ reaction mixture containing $\mathrm{RT}^{2}$ Real-Time SYBR/Fluorescein Green PCR master mix with final concentrations of $10 \mathrm{mM}$ Tris-Cl, $50 \mathrm{mM} \mathrm{KCL}, 2.0 \mathrm{mM} \mathrm{MgCl}_{2}$, $0.2 \mathrm{mM}$ dNTPs, and 2.5 units of HotStart Taq DNA polymerase (Super Array Bioscience Corporation, Frederic, Md, USA). The reaction was completed with addition of $1 \mu \mathrm{L}$ first strand cDNA transcribed from $2 \mu \mathrm{g}$ total RNA, and $0.2 \mathrm{mM} \mathrm{RT}^{2}$ validated PCR primers for PPAR $\gamma$ or GAPDH house keeping gene (Super Array Bioscience). Samples were run in 96-well PCR plates (Bio-Rad, Hercules, Calif, USA) in duplicates, and the results were normalized to GAPDH expression. The amplification protocol was set at $95^{\circ} \mathrm{C}$ for 15 minutes, and 40 cycles each at $\left(95^{\circ} \mathrm{C}\right.$ for 30 seconds, $55^{\circ} \mathrm{C}$ for 30 seconds, and $72^{\circ} \mathrm{C}$ for 30 seconds) followed by a melting curve determination between $55^{\circ} \mathrm{C}$ and $95^{\circ} \mathrm{C}$ to ensure detection of a single PCR product. Real-time PCR products at the end of each assay were combined for each treatment group and stored at $-30^{\circ} \mathrm{C}$ for viewing on agarose gel electrophoresis. Verification of PCR product was confirmed by determination of expected band size and sequence analysis as we described previously [35]. The resulting sequences were matched with previously published rat sequences in Genbank (accession number NM_013124 for PPAR $\gamma$ ) using Chromas 2.31 software (Technelysium Pty ltd, Tewantin Qld 4565, Australia). RNA templates from white adipose tissue and prostate were used to generate standard curves for PPAR $y$ and GAPDH using 10-fold dilutions. Curves were made by plotting threshold cycle ( $C_{t}$ value) for each dilution versus the log of the dilution factor used. Relative differences in expression (fold increase or decrease) were calculated as described previously [36]. Pearson correlation coefficients ( $r$ values) for standard curves were between 0.98 and 0.99 , and amplification efficiency was considered $100 \%$.

2.5. Immunohistochemistry (IHC). Immunolocalization of PPAR $y$ by IHC was performed as described previously by our laboratory [35]. Briefly, cross sections from testes were fixed in $4 \%$ paraformaldehyde for 48 hours, embedded in paraffin, and cut at $5 \mu \mathrm{m}$ thickness. Sections were also fixed in Bouin's fixative (BioSciences) for staining with hematoxylin and eosin. Mounted sections were deparaffinized in HemoD (Scientific Safety Products) and hydrated in distilled water. Antigen retrieval was performed by heating in citrate buffer. Sections were incubated in 5\% normal goat serum containing 2.5\% BSA to reduce nonspecific staining. PPAR $\gamma$ was detected with mouse anti-PPAR $\gamma$ monoclonal antibody (Santa Cruz: sc7273; diluted 1:80 in blocker) and the antibody-antigen complexes were visualized with Alexa 488conjugated goat antimouse IgG (Molecular Probes). Sections were examined with a Nikon TE2000E microscope and digital images were made with an attached Retiga EX CCD digital camera (Q Imaging, Burnaby, BC, Canada).

2.6. Hormonal Assays. Total serum $\mathrm{T}$ (intraassay coefficient of variation (CV) was 4.3\%), E2 (intraassay $\mathrm{CV}$ was $2.3 \%$ ), and intratesticular (intraassay CV was 6\%) level were determined by radioimmunoassay (RIA) using kits from Siemens Medical Solutions Diagnostics (Los Angles, Calif, USA) according to manufacturer's instructions. For intratesticular $\mathrm{T}, 100 \mathrm{mg}$ of testicular tissue was homogenized in $500 \mu \mathrm{L}$ Tris-PBS buffer (0.01 M Tris-HCl; pH 7.4) in plastic tubes. An additional $500 \mu \mathrm{L}$ was added and the homogenate was mixed with eight volumes of diethyl ether. The mixture was then vigorously vortexed and the aqueous phase quickly frozen in a dry ice bath ( $70 \%$ ethanol; dry ice). Extracts were subsequently air dried (warm bath at approximately $50^{\circ} \mathrm{C}$ under the hood) and samples were subsequently resuspended in $500 \mu \mathrm{L}$ PBS-buffer. $50 \mu \mathrm{L}$ of 1:10 diluted sample were used in the COAT-A-COUNT radioimmunoassay and counted in a Cobra D5005-gamma counter (Packard Instrument Co., Downers Grove, Il, USA). All samples were quantified in duplicates in a single assay. FSH and LH were determined by radioimmunoassay at the Endocrine Laboratory, Fort Collins, Colorado State University.

2.7. Serum Adiponectin. Total serum adiponectin concentration was assayed using a sandwich ELISA method (Millipore Corporation, Billerica, Mass, USA) per manufacturer's instructions. The intraassay CV was $1.1 \%$ to $1.3 \%$.

2.8. Statistical Analysis. Analysis of real-time PCR data was performed using a modification of the delta delta $C_{t}$ method $\left(\Delta \Delta C_{t}\right) . \Delta C_{t}$ calculated from real-time PCR data were subjected to analyses of variance using Sigma Stat statistical software (Jandel Scientific, Chicago, IL). Hormonal data were subjected to analysis of variance. Treatment groups with means significantly different $(P<.05)$ from controls were identified using Dunnett's test. When data were not distributed normally, or heterogeneity of variance was identified, analyses were performed on transformed data or ranked data.

\section{Results}

3.1. Blood Glucose and Body Weight. The ZDF rats fed Purina 5008 high fat diet in groups 2 and 3 became diabetic by week 7 of age. By week 15 of age the mean blood glucose concentration, determined shortly before necropsy, was $>600 \mathrm{mg} / \mathrm{dl}$ (above glucose meter range) in ZDF-untreated controls (group 2) versus $123 \pm 1.7 \mathrm{mg} / \mathrm{dl}$ in lean nondiabetic controls (group 1) and 163.6 \pm 17.7 in ZDF rats treated with rosiglitazone (group 3). Rats in all three experimental groups gained weight over time irrespective of treatment. The ZDF-untreated rats mean body weight at week 15 was not significantly different from lean nondiabetic (382.75 \pm 10.94 versus $365 \pm 8.2 \mathrm{gm}$, resp.; $P>.05$ ). In contrast, the mean body weight of ZDF treated rats (group 3) was more than $40 \%$ above that of ZDF untreated rats at week 15 $(638.6 \pm 14.67$ versus $382.75 \pm 10.9 \mathrm{gm}, P<.001)$.

3.2. Serum Adiponectin. Serum adiponectin was determined to confirm PPAR $y$ activation [37]. As expected, treatment with rosiglitazone increased serum adiponectin significantly in ZDF-treated compared with ZDF-untreated rats (46.33 \pm 2.83 versus $12.71 \pm 0.69 \mu \mathrm{g} / \mathrm{mL}, P<.001$ ) or lean nondiabetic 


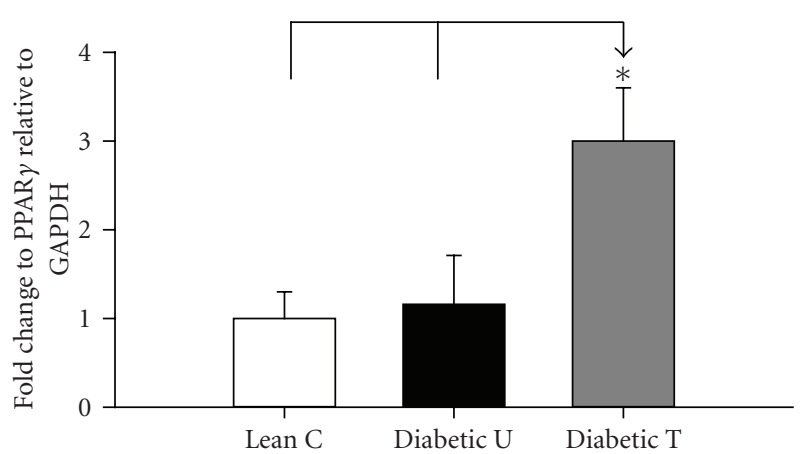

(a)

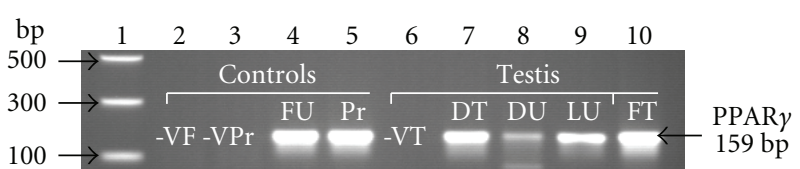

(b)
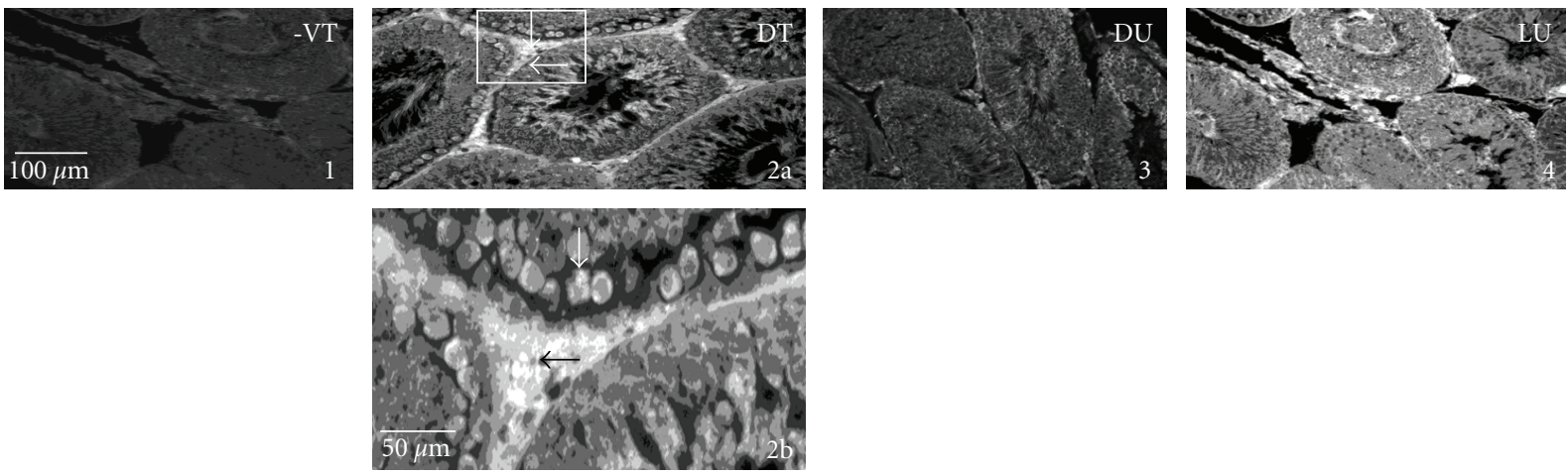

(c)

Figure 1: (a) Real-time PCR analysis of testicular PPAR $\gamma$ mRNA levels in lean nondiabetic controls (Lean C), Zucker diabetic fatty (ZDF) untreated (Diabetic $U$ ), and ZDF rats treated with rosiglitazone (Diabetic T). Data are expressed as mean \pm SE. $n=8$ per group, $* P<.05$. (b) Agarose gel (2\%) showing real-time PCR products generated in (a). Lane 1, DNA markers, lanes 2-3, RNA templates (instead of cDNA) from fat (-VF) and prostate (-VPr) as negative controls. Lanes 4-5, fat from untreated rats (FU) and prostate (Pr) as positive controls. Lanes 6-9, testicular PCR products from RNA negative controls (-VT), diabetic treated (DT), Diabetic untreated (DU), and lean untreated (LU) rats. Lane 10, fat from ZDF-treated rats (FT). (c) Representative IHC of PPAR $\gamma$ protein in the testis of DT (panel 2a with insert box magnified in 2b), DU (panel 3), and LU rats (panel 4). Panel 1, -VT = negative control testis section (minus primary antibody. Arrows indicate PPAR $\gamma$ localization in spermatogonia and in Leydig cells.

untreated rats $(46.33 \pm 2.83$ versus $17.13 \pm 0.95 \mu \mathrm{g} / \mathrm{mL}, P<$ $.001)$. In contrast, adiponectin was significantly reduced by diabetes in ZDF-untreated compared with lean nondiabetic rats $(17.13 \pm 0.95$ versus $12.71 \pm 0.69 \mu \mathrm{g} / \mathrm{mL}, P<.05)$.

3.3. Real-Time PCR, Agarose Gel Electrophoresis and IHC. Real-time PCR data showed that PPAR $y$ mRN was expressed in the testis and was upregulated by more than two folds with rosiglitazone treatment (Figures 1(a) and 1(b)). As shown in the IHC data (Figure 1(c)) PPAR $\gamma$ protein was specifically localized in Leydig cells located in the interstitial space between the seminiferous tubules and in spermatocytes within the inside of seminiferous tubules basement membranes.

3.4. Testicular Morphology and Histopathology. Detachment and disorganization of germ cells was evident in ZDFuntreated rats but there was no significant changes in the overall morphology of seminiferous tubules (Figure 2).
Likewise, treatment did not alter seminiferous tubules morphology but desirably reversed germ cells sloughing (ZDFtreated in panel 2 versus ZDF-untreated in panel 3).

3.5. Serum and Intratesticular T. Total serum and intratesticular $\mathrm{T}$ were not significantly altered by PPAR $\gamma$ activation in the testis (ZDF-treated versus ZDF-untreated, $P>.05$ ) (Figures 3 and 4 ). As expected total serum $T$ was significantly lowered by diabetes (ZDF-untreated or treated versus lean nondiabetic, $P<.05$ ) (Figure 3 ). Surprisingly, the significant reduction in total serum $\mathrm{T}$ in diabetic rats was not associated with a corresponding significant reduction in intratesticular T production (Figure 4). A trend toward lower intratesticular $\mathrm{T}$ in $\mathrm{ZDF}$ versus lean rats was apparent irrespective of rosiglitazone treatment.

3.6. Serum E2. Neither diabetes nor PPAR $y$ activation with rosiglitazone adversely altered serum E2 (Figure 5). 


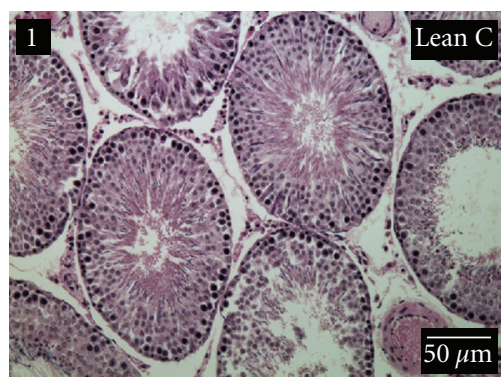

(a)

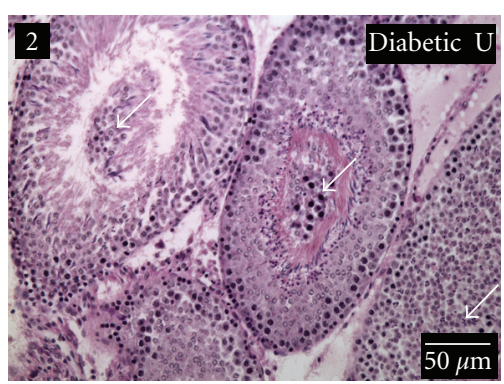

(b)

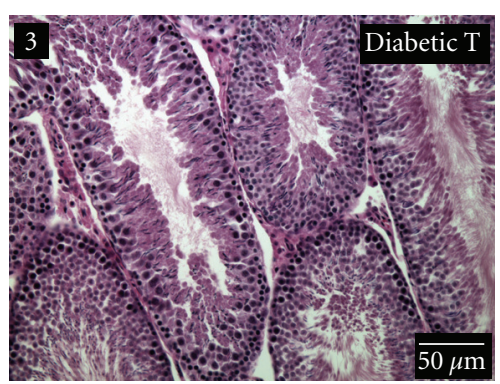

(c)

FIgURE 2: Representative photomicrographs of hematoxylin-eosin-stained sections of testis of nondiabetic Zucker lean control (Lean C, panel 1), Zucker diabetic fatty (ZDF) untreated (Diabetic U, panel 2), and ZDF rats treated with rosiglitazone (Diabetic T, panel 3). Arrows indicate germ cells strewn in the lumen of seminiferous tubules.

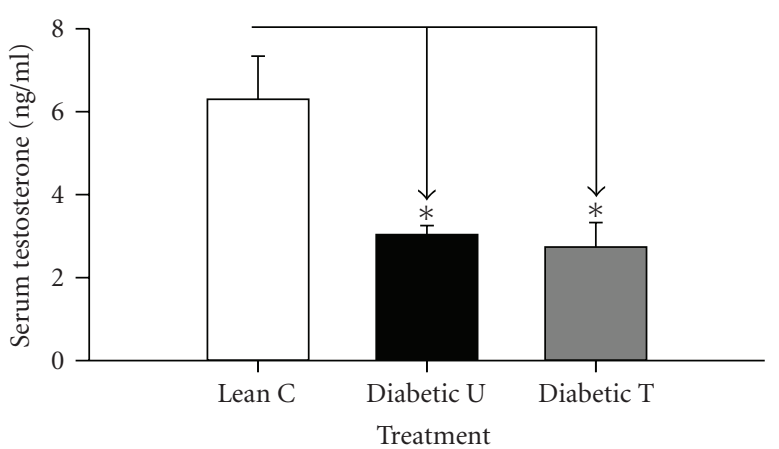

Figure 3: Serum T level in Zucker lean nondiabetic controls (Lean $C$ ), Zucker diabetic fatty- (ZDF-) untreated (Diabetic $U$ ), and ZDF rats treated with rosiglitazone (Diabetic $T)$. Data are expressed as means \pm SE. $n=8$ per group. ${ }^{*} P<.05$.

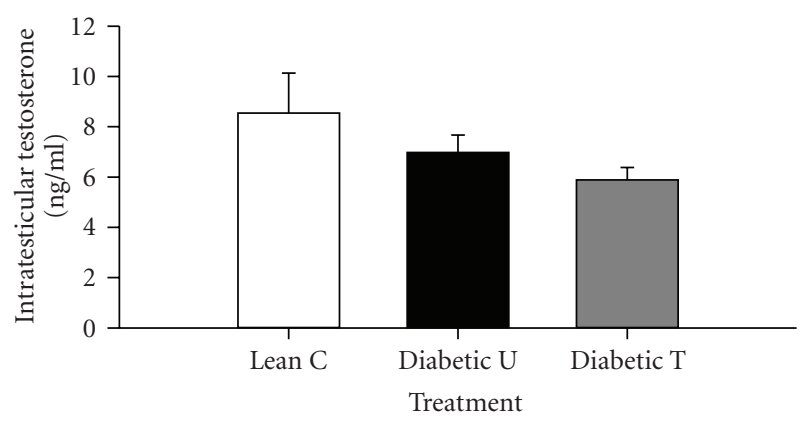

FIgURE 4: Intratesticular T level in Zucker lean nondiabetic controls (Lean C), Zucker diabetic fatty- (ZDF-) untreated (Diabetic $U$ ), and ZDF rats treated with rosiglitazone (Diabetic $T$ ). $n=8$ per group. Data are expressed as means $\pm \mathrm{SE}$.

3.7. Serum FSH and LH. Serum FSH and LH were not significantly altered by activation of PPAR $\gamma$ with rosiglitazone and/or by diabetes $(P>.05)$. The ZDF-untreated rats, however, showed a trend for lower FSH and $\mathrm{LH}$ (ZDF-untreated versus lean nondiabetic) and treatment with rosiglitazone reversed this tendency (ZDF-treated versus ZDF-untreated rats) (Figures 6(a) and 6(b)).

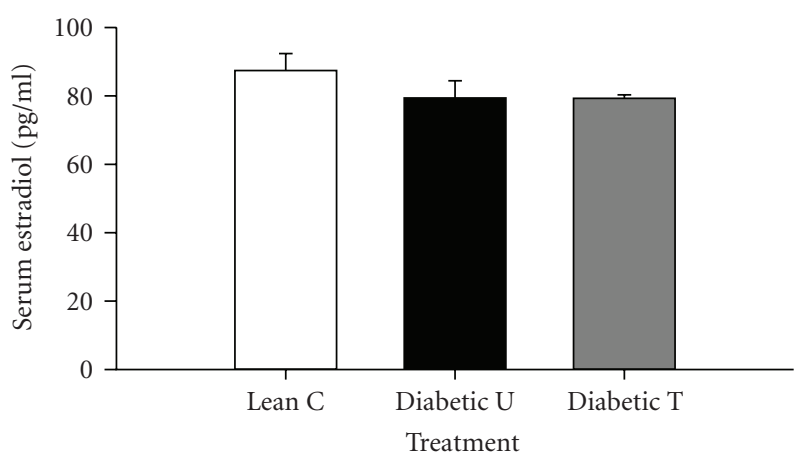

Figure 5: Serum E2 level in Zucker lean nondiabetic controls (Lean $C)$, Zucker diabetic fatty- (ZDF-) untreated (Diabetic $U$ ), and ZDF rats treated with rosiglitazone (Diabetic $T$ ). $n=6$ per group. Data are expressed as means $\pm \mathrm{SE}$.

\section{Discussion}

Rosiglitazone and other TZDs were shown to decrease hyperandrogenemia in women with PCOs and repress major steriodogenic enzymes (reviewed in [26]). Although the in vitro steroidogenic repression potency of rosiglitazone was ranked intermediate between troglitazone and pioglitazone [13], its in vivo impact on sex steroids in diabetic subjects was unknown. Specifically, information on how changes in serum steroids in male diabetic subjects relate to changes in PPAR $\gamma$ activity was lacking. This study documents the link between testicular PPAR $\gamma$ activation with the antidiabetic drug rosiglitazone and male sex hormone profile under diabetic conditions. Daily oral gavage of ZDF rats with rosiglitazone activated PPAR $\gamma$ in the testis and normalized testicular germ cell derangement seen in diabetic testis. The stimulation of systemic and testicular PPAR $\gamma$ activity by rosiglitazone, however, did not significantly alter the concentrations of gonadotropins $\mathrm{LH}$ and FSH, sex steroid T (both total serum and intratesticular) or serum E2.

Systemic activation of PPAR $\gamma$ in this study was evident by the reversal of hyperglycemia, increased serum adipocytokine adiponectin, and by weight gain in ZDF-treated 


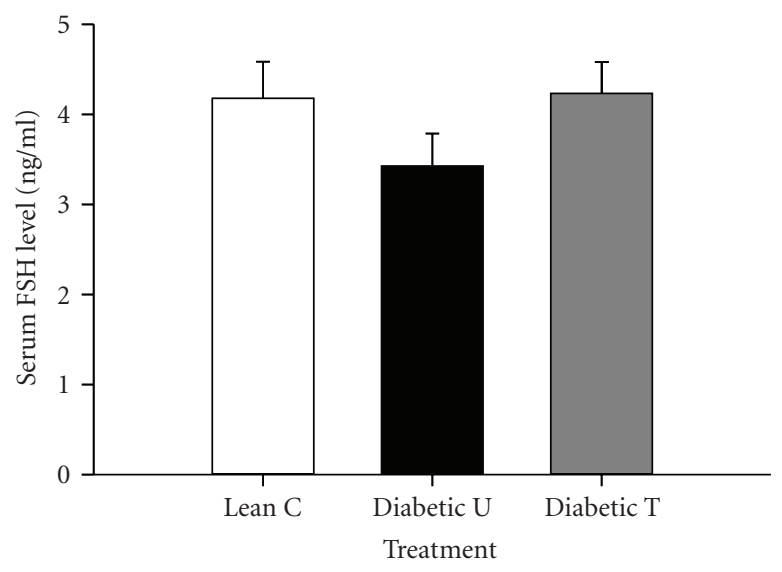

(a)

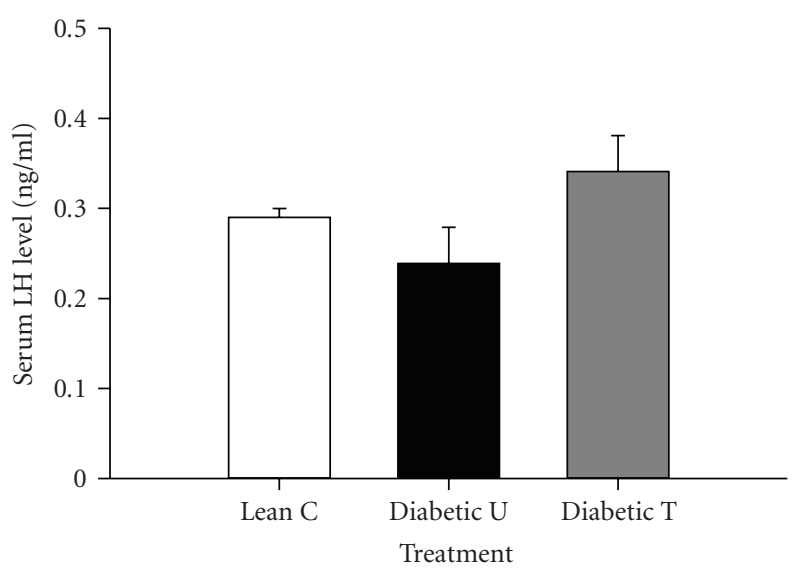

(b)

Figure 6: Serum FSH (a) and LH (b) in Zucker lean nondiabetic controls (Lean C), Zucker diabetic fatty- (ZDF-) untreated (Diabetic U), and ZDF rats treated with rosiglitazone (Diabetic $T$ ). $n=7-8$ per group. Data are expressed as means \pm SE.

rats. These effects are considered biological signatures for rosiglitazone-induced PPAR $y$ activation in typically body fat depots [38, 39]. Specific activation of testicular PPAR $\gamma$ shown here is consistent with other unrelated studies that showed the presence of this receptor in rat testis [40] and its modulation by synthetic chemicals such as phthalate esters $[34,41,42]$. Because PPAR $\gamma$ can also be activated by endogenous ligands such as polyunsaturated fatty acids from diet sources and by metabolites of arachidonic acid [43], contribution of these ligands to the observed up regulation of testicular PPAR $\gamma$ mRNA and protein in ZDF-treated rats could not be ruled out.

Compared to nondiabetic lean rats, ZDF-untreated rats showed consistent structural disorganization of germinal epithelium evident by abnormal accumulation of germ cells in the lumen of seminiferous tubules. This effect likely resulted from diabetes-induced oxidative stress previously recognized in diabetic rat testis [44]. Interestingly, the positive staining of germ cells for PPAR $\gamma$ protein in IHC data suggests that rosiglitazone crosses the blood-testis barrier to enter the adluminal compartment of the seminiferous tubules resulting in activation of PPAR $\gamma$ and reversal of germ cell sloughing. This novel effect is possibly mediated by the reported functional property of PPAR $\gamma$ to ameliorate oxidative stress [11].

As previously known [45], diabetes in this study significantly lowered serum T. Rosiglitazone treatment, however, neither restored nor reduced serum $\mathrm{T}$ in ZDF-treated rats. Paradoxically, the diabetes-induced reduction in serum $\mathrm{T}$ in ZDF-treated and untreated rats were not associated with a corresponding significant drop in intratesticular $\mathrm{T}$ production, or androgen receptor expression (data not shown). Although unexpected, this finding was consistent with the nonsignificant changes observed in serum LH concentration. The unaltered intratesticular $\mathrm{T}$ production contrasted with significantly lowered serum $\mathrm{T}$ concentration may reflect a reduction in sex hormone binding globulin (SHBG) essential for $\mathrm{T}$ transportation in blood [46]. Reagents for determination of rat SHBG are not currently available and attempts to quantify rat SHBG using a human ELISA kit were not successful because of reagents incompatibility.

Rosiglitazone treatment reversed obesity-induced reduction of $\mathrm{T}$ intermediate steroid hormone precursor 17hydroxyprogesterone in the genetically related obese but nondiabetic Zucker rats [22]. In the same study, however, rosiglitazone treatment did not alter total serum T. Compared with the above findings the data in our study allow for differentiation of diabetes steroidogenic effects (ZDFuntreated versus lean nondiabetic rats) from those of PPAR $\gamma$ activation (ZDF-treated versus ZDF-untreated rats) but does not permit a way for separation of obesity effects from those of diabetes. The lack of significant change in total serum $\mathrm{T}$ in the above study was nevertheless consistent with our findings. In both the aforementioned and our study a tendency toward lowered serum $\mathrm{T}$ production was observed in ZDF and Zucker obese versus lean littermates irrespective of treatment. A normal transient $\mathrm{T}$ reduction was reported in 2-4 months old Zucker obese rats [47]. The age of rats at the point of serum collection in this study was 3.75 months and thus the lowered T observed in the ZDF versus lean rats could be a reflection of the above observation in these two genetically related rat models.

Studies that support a steroidogenic regulatory role for PPAR $\gamma$ in women treated with TZDs and in vitro ovarian cell culture models have produced contrasting results as outlined in several reviews [1, 21, 26, 27]. While some in vitro studies showed that rosiglitazone and other TZDs such as troglitazone could inhibit steroidogenic enzymes independent of PPAR $\gamma$ activation $[4,13,16-18,20]$, an inhibitory effect of rosiglitazone was not reflected in total $\mathrm{T}$ and $\mathrm{E} 2$ concentrations in ZDF-treated rats in our study. In summary, our data show that PPAR $\gamma$ activation with rosiglitazone for eight weeks had no negative impact on total sex hormone concentrations in diabetic male rats. This 
finding is firmly in line with studies that showed strong TZDPPAR $\gamma$ activation $[48,49]$ but weaker in vitro steroidogenic inhibitory effects of rosiglitazone [13].

\section{Acknowledgments}

This work was partly supported by Title VI intramural Auburn University grant to M. Mansour, and Diabetes Trust Foundation grant to Elaine Coleman.

\section{References}

[1] C. M. Komar, "Peroxisome proliferator-activated receptors (PPARs) and ovarian function-implications for regulating steroidogenesis, differentiation, and tissue remodeling," Reproductive Biology and Endocrinology, vol. 3, article 41, pp. $1-14,2005$.

[2] R. M. Evans, G. D. Barish, and Y.-X. Wang, "PPARs and the complex journey to obesity," Nature Medicine, vol. 10, no. 4, pp. 355-361, 2004.

[3] B. Desvergne and W. Wahli, "Peroxisome proliferatoractivated receptors: nuclear control of metabolism," Endocrine Reviews, vol. 20, no. 5, pp. 649-688, 1999.

[4] S. Gasic, Y. Bodenburg, M. Nagamani, A. Green, and R. J. Urban, "Troglitazone inhibits progesterone production in porcine granulosa cells," Endocrinology, vol. 139, no. 12, pp. 4962-4966, 1998.

[5] L. A. Moraes, L. Piqueras, and D. Bishop-Bailey, "Peroxisome proliferator-activated receptors and inflammation," Pharmacology \& Therapeutics, vol. 110, no. 3, pp. 371-385, 2006.

[6] M. Wu, D. S. Melichian, E. Chang, M. Warner-Blankenship, A. K. Ghosh, and J. Varga, "Rosiglitazone abrogates bleomycininduced scleroderma and blocks profibrotic responses through peroxisome proliferator-activated receptor- $\gamma$," The American Journal of Pathology, vol. 174, no. 2, pp. 519-533, 2009.

[7] J. E. Milam, V. G. Keshamouni, S. H. Phan, et al., "PPAR- $\gamma$ agonists inhibit profibrotic phenotypes in human lung fibroblasts and bleomycin-induced pulmonary fibrosis," American Journal of Physiology, vol. 294, no. 5, pp. L891-L901, 2008.

[8] T. Kawai, T. Masaki, S. Doi, et al., "PPAR- $\gamma$ agonist attenuates renal interstitial fibrosis and inflammation through reduction of TGF- $\beta$," Laboratory Investigation, vol. 89 , no. 1, pp. 47-58, 2009.

[9] S. S. Chung, M. Kim, B.-S. Youn, et al., "Glutathione peroxidase 3 mediates the antioxidant effect of peroxisome proliferator-activated receptor $\gamma$ in human skeletal muscle cells," Molecular and Cellular Biology, vol. 29, no. 1, pp. 20-30, 2009.

[10] E. Teissier, A. Nohara, G. Chinetti, et al., "Peroxisome proliferator-activated receptor $\alpha$ induces NADPH oxidase activity in macrophages, leading to the generation of LDL with PPAR- $\alpha$ activation properties," Circulation Research, vol. 95, no. 12, pp. 1174-1182, 2004.

[11] P. R. Devchand, O. Ziouzenkova, and J. Plutzky, "Oxidative stress and peroxisome proliferator-activated receptors. Reversing the curse?" Circulation Research, vol. 95, no. 12, pp. 11371139, 2004.

[12] P. D. Schoppee, J. C. Garmey, and J. D. Veldhuis, "Putative activation of the peroxisome proliferator-activated receptor $\gamma$ impairs androgen and enhances progesterone biosynthesis in primary cultures of porcine theca cells," Biology of Reproduction, vol. 66, no. 1, pp. 190-198, 2002.
[13] W. Arlt, R. J. Auchus, and W. L. Miller, "Thiazolidinediones but not metformin directly inhibit the steroidogenic enzymes P450c17 and 3 $\beta$-hydroxysteroid dehydrogenase," The Journal of Biological Chemistry, vol. 276, no. 20, pp. 16767-16771, 2001.

[14] H. Vierhapper, P. Nowontny, and W. Waldhäusl, "Reduced production rates of testosterone and dihydrotestosterone in healthy men treated with rosiglitazone," Metabolism: Clinical and Experimental, vol. 52, no. 2, pp. 230-232, 2003.

[15] G. L. Rubin, J. H. Duong, C. D. Clyne, et al., "Ligands for the peroxisomal proliferator-activated receptor $\gamma$ and the retinoid $\mathrm{X}$ receptor inhibit aromatase cytochrome $\mathrm{P} 450$ (CYP19) expression mediated by promoter II in human breast adipose," Endocrinology, vol. 143, no. 8, pp. 2863-2871, 2002.

[16] S. Gasic, M. Nagamani, A. Green, and R. J. Urban, "Troglitazone is a competitive inhibitor of $3 \beta$-hydroxysteroid dehydrogenase enzyme in the ovary," American Journal of Obstetrics \& Gynecology, vol. 184, no. 4, pp. 575-579, 2001.

[17] J. D. Veldhuis, G. Zhang, and J. C. Garmey, "Troglitazone, an insulin-sensitizing thiazolidinedione, represses combined stimulation by LH and insulin of de novo androgen biosynthesis by thecal cells in vitro," The Journal of Clinical Endocrinology \& Metabolism, vol. 87, no. 3, pp. 1129-1133, 2002.

[18] P. Kempná, G. Hofer, P. E. Mullis, and C. E. Flück, "Pioglitazone inhibits androgen production in NCI-H295R cells by regulating gene expression of CYP17 and HSD3B2," Molecular Pharmacology, vol. 71, no. 3, pp. 787-798, 2007.

[19] A. Dunaif, D. Scott, D. Finegood, B. Quintana, and R. Whitcomb, "The insulin-sensitizing agent troglitazone improves metabolic and reproductive abnormalities in the polycystic ovary syndrome," The Journal of Clinical Endocrinology \& Metabolism, vol. 81, no. 9, pp. 3299-3306, 1996.

[20] Y.-M. Mu, T. Yanase, Y. Nishi, et al., "Insulin sensitizer, troglitazone, directly inhibits aromatase activity in human ovarian granulosa cells," Biochemical and Biophysical Research Communications, vol. 271, no. 3, pp. 710-713, 2000.

[21] C. E. Minge, R. L. Robker, and R. J. Norman, "PPAR gamma: coordinating metabolic and immune contributions to female fertility," PPAR Research, vol. 2008, Article ID 243791, 19 pages, 2008.

[22] C. Fürnsinn, P. Nowotny, B. Brunmair, et al., "Thiazolidinediones influence plasma steroids of male obese Zucker rats," Endocrinology, vol. 143, no. 1, pp. 327-330, 2002.

[23] The Rotterdam ESHRE/ASRM-Sponsored PCOS Consensus Workshop Group, "Revised 2003 consensus on diagnostic criteria and long-term health risks related to polycystic ovary syndrome," Fertility and Sterility, vol. 81, no. 1, pp. 19-25, 2004.

[24] A. Dunaif, "Adrenal disorders and polycystic ovary syndrome," Hormone Research, vol. 37, supplement 3, pp. 39-44, 1992.

[25] S. Franks, "Polycystic ovary syndrome," The New England Journal of Medicine, vol. 333, no. 13, pp. 853-861, 1995.

[26] B. Toth, D. Hornung, C. Scholz, S. Djalali, K. Friese, and U. Jeschke, "Peroxisome proliferator-activated receptors: new players in the field of reproduction," American Journal of Reproductive Immunology, vol. 58, no. 3, pp. 289-310, 2007.

[27] P. Froment, F. Gizard, D. Defever, B. Staels, J. Dupont, and P. Monget, "Peroxisome proliferator-activated receptors in reproductive tissues: from gametogenesis to parturition," Journal of Endocrinology, vol. 189, no. 2, pp. 199-209, 2006.

[28] A. Dunaif, "Drug insight: insulin-sensitizing drugs in the treatment of polycystic ovary syndrome-a reappraisal," Nature Reviews Endocrinology, vol. 4, no. 5, pp. 272-283, 2008. 
[29] J. N. Feige, L. Gelman, D. Rossi, et al., "The endocrine disruptor monoethyl-hexyl-phthalate is a selective peroxisome proliferator-activated receptor $\gamma$ modulator that promotes adipogenesis," The Journal of Biological Chemistry, vol. 282, no. 26, pp. 19152-19166, 2007.

[30] N. J. Barlow, S. L. Phillips, D. G. Wallace, M. Sar, K. W. Gaido, and P. M. D. Foster, "Quantitative changes in gene expression in fetal rat testes following exposure to di(n-butyl) phthalate," Toxicological Sciences, vol. 73, no. 2, pp. 431-441, 2003.

[31] K. P. Lehmann, S. Phillips, M. Sar, P. M. D. Foster, and K. W. Gaido, "Dose-dependent alterations in gene expression and testosterone synthesis in the fetal testes of male rats exposed to di(n-butyl) phthalate," Toxicological Sciences, vol. 81 , no. 1 , pp. 60-68, 2004.

[32] C. J. Thompson, S. M. Ross, and K. W. Gaido, "Di( $n$-butyl) phthalate impairs cholesterol transport and steroidogenesis in the fetal rat testis through a rapid and reversible mechanism," Endocrinology, vol. 145, no. 3, pp. 1227-1237, 2004.

[33] J. Borch, M. Axelstad, A. M. Vinggaard, and M. Dalgaard, "Diisobutyl phthalate has comparable anti-androgenic effects to di-n-butyl phthalate in fetal rat testis," Toxicology Letters, vol. 163, no. 3, pp. 183-190, 2006.

[34] J. Borch, S. B. Metzdorff, A. M. Vinggaard, L. Brokken, and M. Dalgaard, "Mechanisms underlying the anti-androgenic effects of diethylhexyl phthalate in fetal rat testis," Toxicology, vol. 223, no. 1-2, pp. 144-155, 2006.

[35] M. M. Mansour, H. O. Goyal, T. D. Braden, et al., "Activation of penile proadipogenic peroxisome proliferator-activated receptor $\gamma$ with an estrogen: interaction with estrogen receptor alpha during postnatal development," PPAR Research, vol. 2008, Article ID 651419, 10 pages, 2008.

[36] J. Vandesompele, K. De Preter, F. Pattyn, et al., "Accurate normalization of real-time quantitative RT-PCR data by geometric averaging of multiple internal control genes," Genome Biology, vol. 3, no. 7, article research0034.1-0034.11, pp. 1-12, 2002.

[37] J. E. Caminos, R. Nogueiras, F. Gaytán, et al., "Novel expression and direct effects of adiponectin in the rat testis," Endocrinology, vol. 149, no. 7, pp. 3390-3402, 2008.

[38] M. Gurnell, "Peroxisome proliferator-activated receptor $\gamma$ and the regulation of adipocyte function: lessons from human genetic studies," Best Practice \& Research Clinical Endocrinology \& Metabolism, vol. 19, no. 4, pp. 501-523, 2005.

[39] R. M. Evans, G. D. Barish, and Y.-X. Wang, "PPARs and the complex journey to obesity," Nature Medicine, vol. 10, no. 4, pp. 355-361, 2004.

[40] O. Braissant, F. Foufelle, C. Scotto, M. Dauça, and W. Wahli, "Differential expression of peroxisome proliferator-activated receptors (PPARs): tissue distribution of PPAR- $\alpha,-\beta$, and $-\gamma$ in the adult rat," Endocrinology, vol. 137, no. 1, pp. 354-366, 1996.

[41] N. Bhattacharya, J. M. Dufour, M.-N. Vo, J. Okita, R. Okita, and K. H. Kim, "Differential effects of phthalates on the testis and the liver," Biology of Reproduction, vol. 72, no. 3, pp. 745754, 2005.

[42] J. Y. Ryu, B. M. Lee, S. Kacew, and H. S. Kim, "Identification of differentially expressed genes in the testis of Sprague-Dawley rats treated with di(n-butyl) phthalate," Toxicology, vol. 234, no. 1-2, pp. 103-112, 2007.

[43] S. A. Kliewer, S. S. Sundseth, S. A. Jones, et al., "Fatty acids and eicosanoids regulate gene expression through direct interactions with peroxisome proliferator-activated receptors $\alpha$ and $\gamma$," Proceedings of the National Academy of Sciences of the United States of America, vol. 94, no. 9, pp. 4318-4323, 1997.
[44] B. Shrilatha and Muralidhara, "Early oxidative stress in testis and epididymal sperm in streptozotocin-induced diabetic mice: its progression and genotoxic consequences," Reproductive Toxicology, vol. 23, no. 4, pp. 578-587, 2007.

[45] J. B. Farrell, A. Deshmukh, and A. A. Baghaie, "Low testosterone and the association with type 2 diabetes," The Diabetes Educator, vol. 34, no. 5, pp. 799-806, 2008.

[46] G. L. Hammond, "Extracellular steroidbinding proteins," in Steroid Hormone Action, Frontiers in Molecular Biology, pp. 1-25, IRL Press at Oxford University, Oxford, UK, 1993.

[47] R. A. Young, R. Frink, and C. Longcope, "Serum testosterone and gonadotropins in the genetically obese male Zucker rat," Endocrinology, vol. 111, no. 3, pp. 977-981, 1982.

[48] G. Berger, P. Bailey, C. Biswas, et al., "Thiazolidinediones produce a conformational change in peroxisomal proliferatoractivated receptor-gamma: binding and activation correlate with antidiabetic actions in $\mathrm{db} / \mathrm{db}$ mice," Endocrinology, vol. 137, no. 10, pp. 4189-4195, 1996.

[49] T. M. Willson, J. E. Cobb, D. J. Cowan, et al., "The structureactivity relationship between peroxisome proliferatoractivated receptor $\gamma$ agonism and the antihyperglycemic activity of thiazolidinediones," Journal of Medicinal Chemistry, vol. 39, no. 3, pp. 665-668, 1996. 


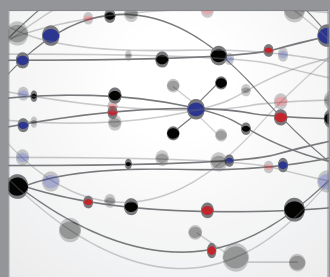

The Scientific World Journal
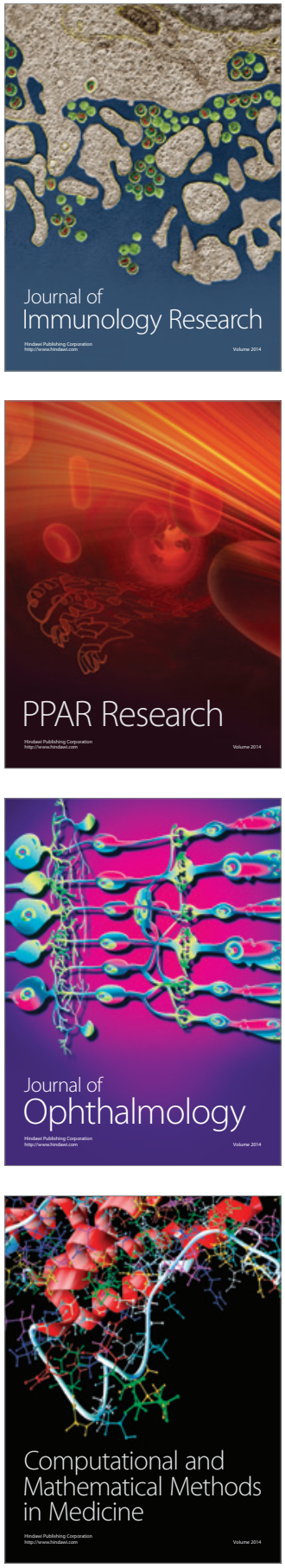

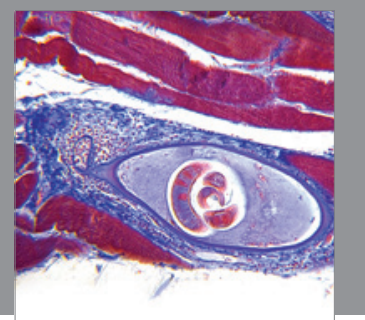

Gastroenterology

Research and Practice
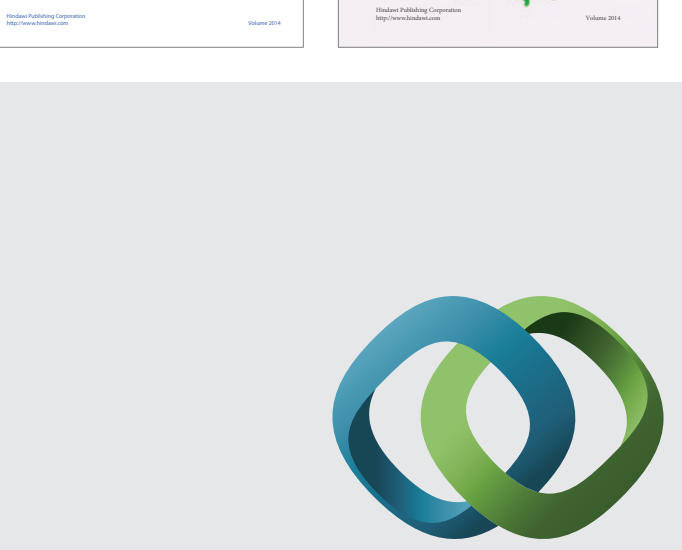

\section{Hindawi}

Submit your manuscripts at

http://www.hindawi.com
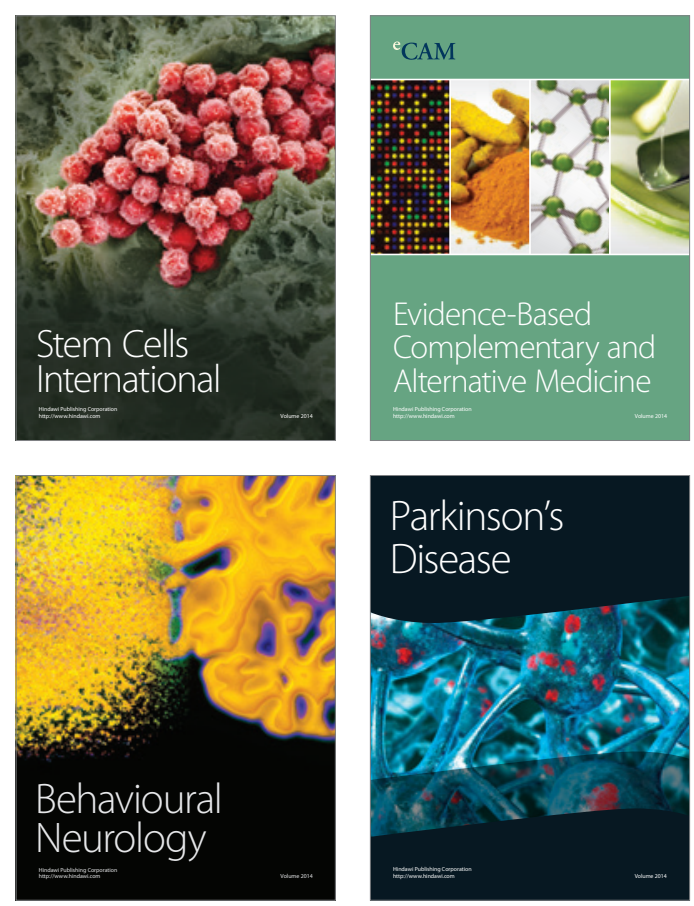

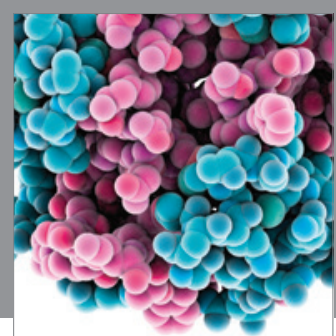

Journal of
Diabetes Research

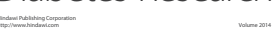

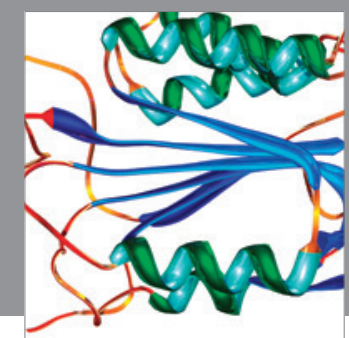

Disease Markers
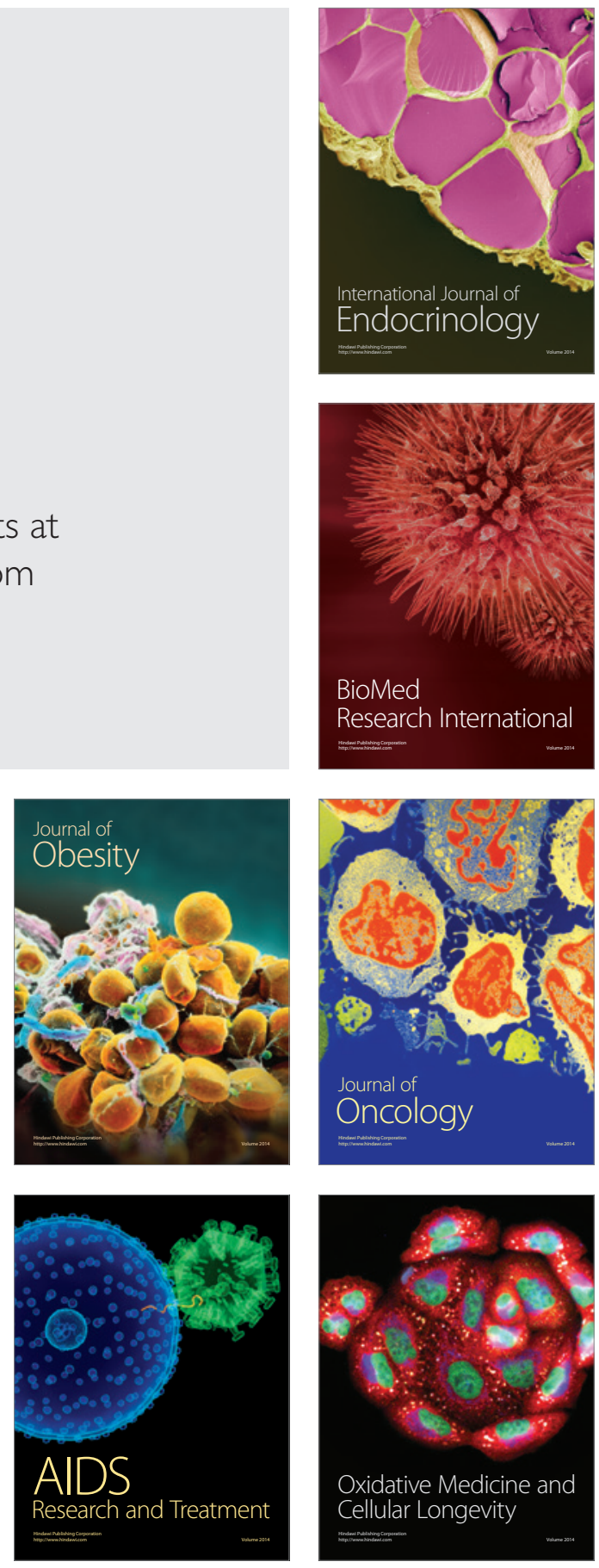